\begin{tabular}{|c|c|c|}
\hline \multicolumn{2}{|c|}{ REPORT DOCUMENTATION PAGE } & $\begin{array}{l}\text { Form Approved } \\
\text { OMB No. 0704-0188 }\end{array}$ \\
\hline \multicolumn{3}{|c|}{ 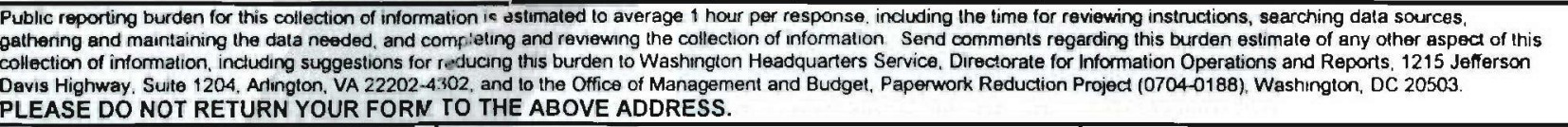 } \\
\hline $\begin{array}{l}\text { 1. REPORT DATE (DD-MM-YYYM } \\
\text { 11/29/05 }\end{array}$ & $\begin{array}{l}\text { 2. REPORT TYPE } \\
\text { Final }\end{array}$ & $\begin{array}{l}\text { 3. DATES COVERED (From - T0) } \\
8 / 27 / 98 \text { to } 9 / 30 / 04\end{array}$ \\
\hline \multirow{4}{*}{\multicolumn{2}{|c|}{$\begin{array}{l}\text { 4. TITLE AND SUBTITLE } \\
\text { Characterization of biologically produced colored dissolved organic matter } i \\
\text { seawater }\end{array}$}} & \multirow[t]{2}{*}{ 5a. CONTRACT NUMBERS } \\
\hline & & \\
\hline & & $\begin{array}{l}\text { 5b. GRANT NUMBER } \\
\text { N00014-98-1-0579 \& N00014-03-1-0387 }\end{array}$ \\
\hline & & $\begin{array}{l}\text { 5c. PROGRAM ELEMENT NUMBER } \\
\text { 04PRO00868-00 }\end{array}$ \\
\hline \multirow{2}{*}{\multicolumn{2}{|c|}{$\begin{array}{l}\text { 6. AUTHOR(S) } \\
\text { Daniel J. Repeta }\end{array}$}} & 5d. PROJECT NUMBER \\
\hline & & 5e. TASK NUMBER \\
\hline & & 5f. WORK UNIT NUMBER \\
\hline \multicolumn{3}{|c|}{$\begin{array}{l}\text { 7. PERFORMING ORGANIZATION NAME(S) AND ADDRESS(ES) } \\
\text { Woods Hole Oceanographic Insititution } \\
\text { Woods Hole, MA } 02543\end{array}$} \\
\hline \multirow{2}{*}{\multicolumn{2}{|c|}{$\begin{array}{l}\text { 9. SPONSORING/MONITORING AGENCY NAME(S) AND ADDRESS(ES) } \\
\text { ONR } \\
\text { Ballston Center Tower One } \\
\text { 800 North Qunicy Street } \\
\text { Arlington, VA 22217-5660 }\end{array}$}} & 10. SPONSORING/MONITORING ACRONYM(S) \\
\hline & & $\begin{array}{l}\text { 11. SPONSORINGIMONITORING AGENCY } \\
\text { REPORT NUMBER }\end{array}$ \\
\hline \multicolumn{3}{|c|}{ 12. DISTRIBUTION/AVAILABILITY STATEMENT } \\
\hline \multicolumn{3}{|l|}{ 13. SUPPLEMENTARY NOTES } \\
\hline \multicolumn{3}{|c|}{ 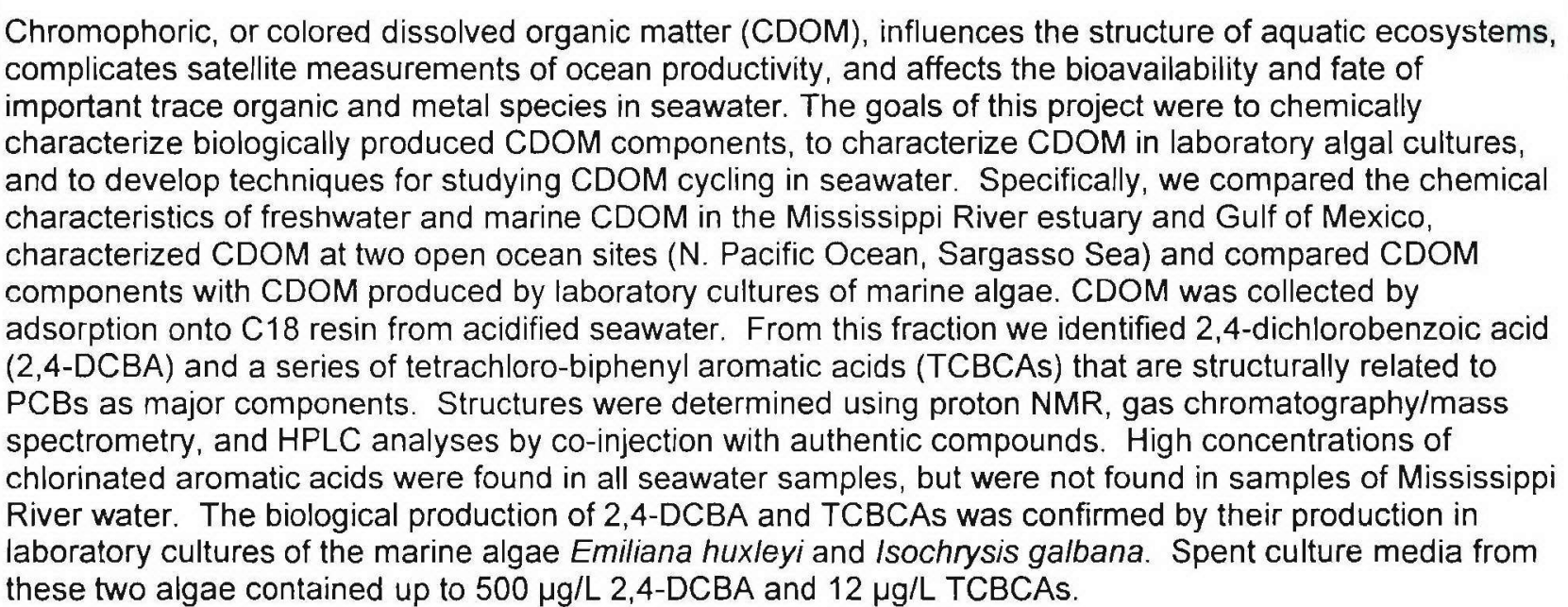 } \\
\hline
\end{tabular}




\begin{tabular}{|l|l|l|l|l|l|}
\hline 15. SUBJECT TERMS \\
\hline
\end{tabular}




\title{
Characterization of Biologically Produced Colored Dissolved Organic Matter in Seawater
}

\author{
Daniel J. Repeta \\ Woods Hole Oceanographic Institution \\ Marine Chemistry and Geochemistry \\ Woods Hole, MA 02543-1543 \\ phone: (508)-289-2635 fax: (508)-457-2164 e-mail: drepeta@whoi.edu
}

\section{Grant\# N00014-98-1-0579 \& N00014-03-1-0387}

Chromophoric, or colored dissolved organic matter (CDOM), influences the structure of aquatic ecosystems, complicates satellite measurements of ocean productivity, and affects the bioavailability and fate of important trace organic and metal species $(1-4)$ in seawater. CDOM absorbs much of the ultraviolet and near ultraviolet radiation penetrating the ocean, and in some oceanic regimes CDOM absorption in the visible may substantially reduce the penetration of photosynthetically available radiation, thereby limiting primary production (5). Photochemical transformation of CDOM destroys recalcitrant organic carbon and leads to the production of low molecular weight organic compounds that act as substrates for microbial production $(6,7)$. Photochemical transformation of CDOM also leads to the production of reactive oxygen species that oxidize iron, copper and other trace metals, affecting their cycling and biological availability $(8)$.

The sources of marine CDOM are not well known or understood. Degradation of higher plant carbon in soil yields humic substances, structurally complex macromolecular organic matter rich in aromatic and carboxylic acid functional groups, both of which absorb strongly in the ultraviolet (9). Rivers supply a significant amount of humic substances leached from soils and decomposing terrestrial organic matter to the coastal ocean (10). Comparisons between the chemical composition, stable and radioisotopes, and optical properties of freshwater and coastal CDOM show similarities between these two environments, and terrestrial organic matter is thought to be the major source of CDOM in the coastal zone. However, terrestrial humic substances are rapidly removed from seawater by photobleaching, and do not supply a significant amount of CDOM to the open ocean. (1I) 
In highly productive coastal regions and throughout most of the global ocean, insitu biological production is the major source of CDOM. At some open ocean sites, CDOM fluctuates on seasonal cycles that can be coupled to cycles of marine organic matter production and remineralization $(12,13)$. CDOM concentrations are high in the chlorophyll maxima of the Arabian Sea and were correlated with the upwelling of colder, nutrient rich subsurface water, consistent with a source related to biological activity (14). Likewise, in situ measurements of CDOM absorption at $412 \mathrm{~nm}$ were positively correlated with oxygen super saturation and Chlorophyll- $a$ absorption at a highly productive'coastal site, suggesting rapid in situ production of CDOM associated with primary production (15). However, few discrete components of CDOM have been reported. Excitation- emission matrix spectroscopy has identified the presence distinct excitation maxima at $275 \mathrm{~nm}, 312 \mathrm{~nm}$ and $398 \mathrm{~nm}$ that are attributed to proteins, marine humic substances and chlorophyll $(16,17)$. Proteins, amino acids, marine humic substances and chlorophyll have all been identified in the dissolved or colloidal phase, but together account for only a small fraction of CDOM absorption at open ocean sites.

Several studies have used absorption and fluorescence spectroscopy in combination with capillary gel electrophoresis and high-pressure liquid chromatography (HPLC) to further characterize CDOM. Marine CDOM extracted from seawater by adsorption onto hydrophobic resin has been separated by reverse phase HPLC (18) into different fractions that display different fluorescence spectra with multiple maxima between $300-600 \mathrm{~nm}\left(\lambda_{\mathrm{ex}} 300-450 \mathrm{~nm}\right)(19)$. Separation by gradient elution HPLC showed improved resolution of a very complex mixture of CDOM components, but most components remained unresolved. Using HPLC, marine CDOM appears as a complex mixture of $>30$ discrete components superimposed on a broad, featureless baseline. Fluorescence bands observed in the total CDOM extracts could be chromatographically separated into different fractions, and distinct CDOM components were isolated from marine and fresh waters, suggesting compositional differences for at least some CDOM components in different environments (20).

The goals of this project were to chemically characterize biologically produced CDOM components, to characterize CDOM in laboratory algal cultures, and to develop techniques for studying CDOM cycling in seawater. Specifically, we compared the 
chemical characteristics of freshwater and marine CDOM in the Mississippi River estuary and Gulf of Mexico, characterized CDOM at two open ocean sites (N. Pacific Ocean, Sargasso Sea) and compared CDOM components with CDOM produced by laboratory cultures of marine algae.

\section{Identification of CDOM components in fresh and marine waters}

Sampling and Analyses. Water samples (20-200 L) were collected from two rivers; the Atchafalaya River ( $28^{\circ} 37^{\prime} \mathrm{N}, 90^{\circ} 46^{\prime} \mathrm{W}, 0.1 \mathrm{ppt}$ Salinity) and Mississippi River ( $28^{\circ} 56^{\prime} \mathrm{N}, 8^{\circ} 25^{\prime} \mathrm{W}, 0.857 \mathrm{ppt}$ ), five marine sites, including the North Pacific Ocean (June, 2002; surface and $1800 \mathrm{~m}, 2^{\circ} 25^{\prime} \mathrm{N}, 156^{\circ} 18^{\prime} \mathrm{W}$ ), the Sargasso Sea (March 2003 from the Bermuda Biological Station in St. Georges, Bermuda, surface, $38^{\circ} 20^{\prime} \mathrm{N}$, $64^{\circ} 48^{\prime} \mathrm{W}$ ), Vineyard Sound (September, 2002; Woods Hole, MA; surface, $41^{\circ} 31^{\prime} \mathrm{N}$, $70^{\circ} 40^{\prime} \mathrm{W}$ ), and the Gulf of Mexico (all surface, $28^{\circ} 39^{\prime} \mathrm{N}, 89^{\circ} 83^{\prime} \mathrm{W}, 36.33 \mathrm{ppt}$ ), and two lacustrine sites including Mississippi River mixed salinity $\left(29^{\circ} 02^{\prime} \mathrm{N}, 89^{\circ} 46^{\prime} \mathrm{W}, 15.03\right.$ ppt), and Mississippi River aged plume (29 $\left.10^{\prime} \mathrm{N}, 89^{\circ} 36^{\prime} \mathrm{W}, 15.89 \mathrm{ppt}\right)$ samples. The Mississippi River and Gulf of Mexico samples were taken aboard the R/V Pelican using an impellor pump and Teflon tubing. Pacific Ocean surface samples were collected from the uncontaminated seawater supply aboard the R/V Melville and deep samples were collected in 30 L Niskin bottles. The Vineyard Sound sample was collected from the Coastal Research Laboratory's seawater supply at the Woods Hole Oceanographic Institution.

All samples were filtered to remove bacteria and small particles. Samples were pumped through cleaned $(10 \% \mathrm{HCl}) 0.2 \mu \mathrm{m}$ filter cartridges or two stage $(0.7$ and 0.2 $\mu \mathrm{m}$, Criticap, Gelman Corp.) polysulfone membrane cartridges into $200 \mathrm{~L}$ fluorinated HDPE containers. Subsamples were collected for total DOC analysis. After filtration, the samples were acidified to $\mathrm{pH} 3$ with either glacial acetic acid (Acros Organics, USA) or concentrated hydrochloric acid (LabChem, USA). Chromophoric dissolved organic matter was extracted by solid phase extraction onto $\mathrm{C}_{18}$ resin (Aldrich, Supelco) after the method of Armador et al. (21). Prior to use, the $\mathrm{C}_{18}$ packing was washed and conditioned (per $160 \mathrm{~g}$ of material) with $800 \mathrm{~mL}$ hexane, $800 \mathrm{~mL}$ acetone, $800 \mathrm{~mL}$ methanol, $800 \mathrm{~mL}$ 
high purity low carbon water, $400 \mathrm{~mL} 0.1 \mathrm{M} \mathrm{HCl}$, high purity low carbon water until pH neutral, $400 \mathrm{~mL}$ methanol, and finally air-dried for storage until used in the CDOM extractions. Following seawater extraction, the column was washed with $40-80 \mathrm{~mL}$ of high purity low carbon water to remove excess salts and the CDOM eluted with $100 \mathrm{~mL}$ of HPLC grade methanol (Fisher Scientific, USA) followed by $100 \mathrm{ml}$ of $11.2 \mathrm{~N} \mathrm{NH}_{4} \mathrm{OH}$ (Fisher Scientific, certified ACS). The methanol was evaporated to dryness under vacuum to produce a yellow-brown solid. A small, 1-3 mL, volume of methanol was used to redissolve the material, which was then briefly centrifuged to remove particulates (undissolved salts). The ammonium hydroxide fraction was not characterized in this study.

We analyzed several different types of sample blanks to monitor the presence of contaminants in our samples, and to determine if specific CDOM components could be introduced by contamination. Solid phase extraction columns packed with $\mathrm{C}_{18}$ resin were taken into the field, returned to the laboratory and processed as samples. We also filled sample containers with artificial seawater made from combusted $\left(450^{\circ} \mathrm{C}\right.$, overnight) salts and low carbon, deionized (Milli-Q) water. These blanks were processed in an identical manner to samples, using the same equipment, resins, acids, and solvents as our samples. Blanks contained very low levels of $\operatorname{CDOM~(~}<1 \%$ of sample amounts) which, when analyzed by HPLC yielded compounds with different retention times and UV spectra than CDOM components reported in this study.

UV-Vis absorbance spectra of total methanol extracts and HPLC purified compounds were acquired in methanol on a HP8452A diode array spectrophotometer. CDOM was separated into pure compounds by reverse-phase high performance liquid chromatography (RP-HPLC). Samples were purified on a $15 \mathrm{~cm}$ column (4.5 mm i.d.. Supelco Discovery HS). Initial separations were performed on a gradient from $100 \%$ aqueous ammonium acetate $(50 \mathrm{mM}, \mathrm{pH}=8)$ (Fisher Scientific, HPLC grade) to $100 \%$ methanol with a flow rate of $1 \mathrm{~mL} / \mathrm{min}$ (ammonium acetate (aq):methanol; time) / (100:0; $2.5 \mathrm{~min}) /(40: 60 ; 17.5 \mathrm{~min}) /(0: 100 ; 27 \mathrm{~min})$. Fractions collected from the this separation were further purified using a $50 \mathrm{mM}$ ammonium acetate : acetonitrile (Fisher Scientific, HPLC grade) : methanol gradient at a flow rate of $1 \mathrm{~mL} / \mathrm{min}(70: 25: 5 ; 2.5$ $\mathrm{min}) /(0: 70: 30 ; 12.5 \mathrm{~min}) /(0: 15: 85 ; 25 \mathrm{~min})$ (Figure 1). Purified CDOM components 
were dried under nitrogen to remove methanol and lyophilized to remove the aqueous ammonium acetate.

NMR spectra were acquired on a Bruker Avance 400 DPX spectrometer at 400 MHz. Samples were dissolved in perdeuterated methanol (Aldrich, 99.95 atom\% D) and chemical shifts referenced to methanol at $3.5 \mathrm{ppm}$. Liquid chromatography -MS-MS spectra were obtained on a Micromass (Manchester, England) Quattro II mass spectrometer (triple quadrupole) with electrospray ionization (ESI). The LC was conducted with a Thermo Hypersil-Keystone (Bellefonte, PA) Beta Basic $\mathrm{C}_{18}$ using a solvent program of $50 \mathrm{mM}$ ammonium acetate in water to methanol $(100: 0 ; 2.5 \mathrm{~min} /$ $40: 60 ; 15 \mathrm{~min} / 0: 100 ; 25 \mathrm{~min} / 0: 100 ; 35 \mathrm{~min})$.

In preparation for GC-MS analysis, CDOM was methylated to convert carboxylic acids into methyl esters. Methanol solutions of CDOM were treated with 5\% acetyl chloride in methanol at $50{ }^{\circ} \mathrm{C}$ overnight. The resulting acidic solution was neutralized with $200 \mathrm{mM}$ ammonium carbonate and extracted twice with dichloromethane. The dichloromethane solution was evaporated to approximately $10 \mu \mathrm{L}$ prior to splitless injection into a Hewlett Packard 5972 GC-MS, which was equipped with a Supelco (Bellefonte, PA) Equity-5: $30 \mathrm{~m} \mathrm{l,0.25} \mathrm{mm} \mathrm{i.d.,} 0.25 \mu \mathrm{m}$ coating. Helium was used as a carrier gas at a velocity of $40 \mathrm{~cm} / \mathrm{s}$, and $70 \mathrm{eV}$ electron ionization mass spectra were collected. A temperature gradient program of $50^{\circ} \mathrm{C}$ (hold $2 \mathrm{~min}$ ) $/ \mathrm{ramp}$ at $8^{\circ} \mathrm{C}$ to $300^{\circ} \mathrm{C}$ $/$ hold $300^{\circ} \mathrm{C}$ for $10 \mathrm{~min}$. The compounds of interest were identified through the use of extracted ion chromatograms for the predicted molecular weights of the derivatized products.

Results from the Atchafalaya and Mississippi River estuaries. Samples were taken in the Atchafalya and Mississippi Rivers as representative of freshwater CDOM (S $=0.1$ and $0.857 \mathrm{ppt})$, at an intermediate salinity station (15.03 ppt), and in the Gulf of Mexico (36.33 ppt). A plume of Mississippi River water (15.89 ppt) was followed into the Gulf of Mexico with a drifter and also sampled (aged plume sample) (Fig. 1). Chromatograms showing RP-HPLC separations measured at $240 \mathrm{~nm}$, are distinct for every sample (Fig. 2). The Mississippi and Atchafalaya River samples appear mainly as a large unresolved hump between 6-25 minutes. Small peaks detected in the Mississippi River sample are presumed to result from mixing with a small amount of ocean water. 
The Aged Plume and Mixed Salinity samples, which have intermediate salinities, show a large hump due to the presence of the undifferentiated CDOM material. On top of this hump are several small but distinct peaks with same retention time as peaks identified in the Gulf of Mexico sample, where six distinct peaks can be seen. Here, the broad hump ascribed to undifferentiated CDOM material is undetectable.

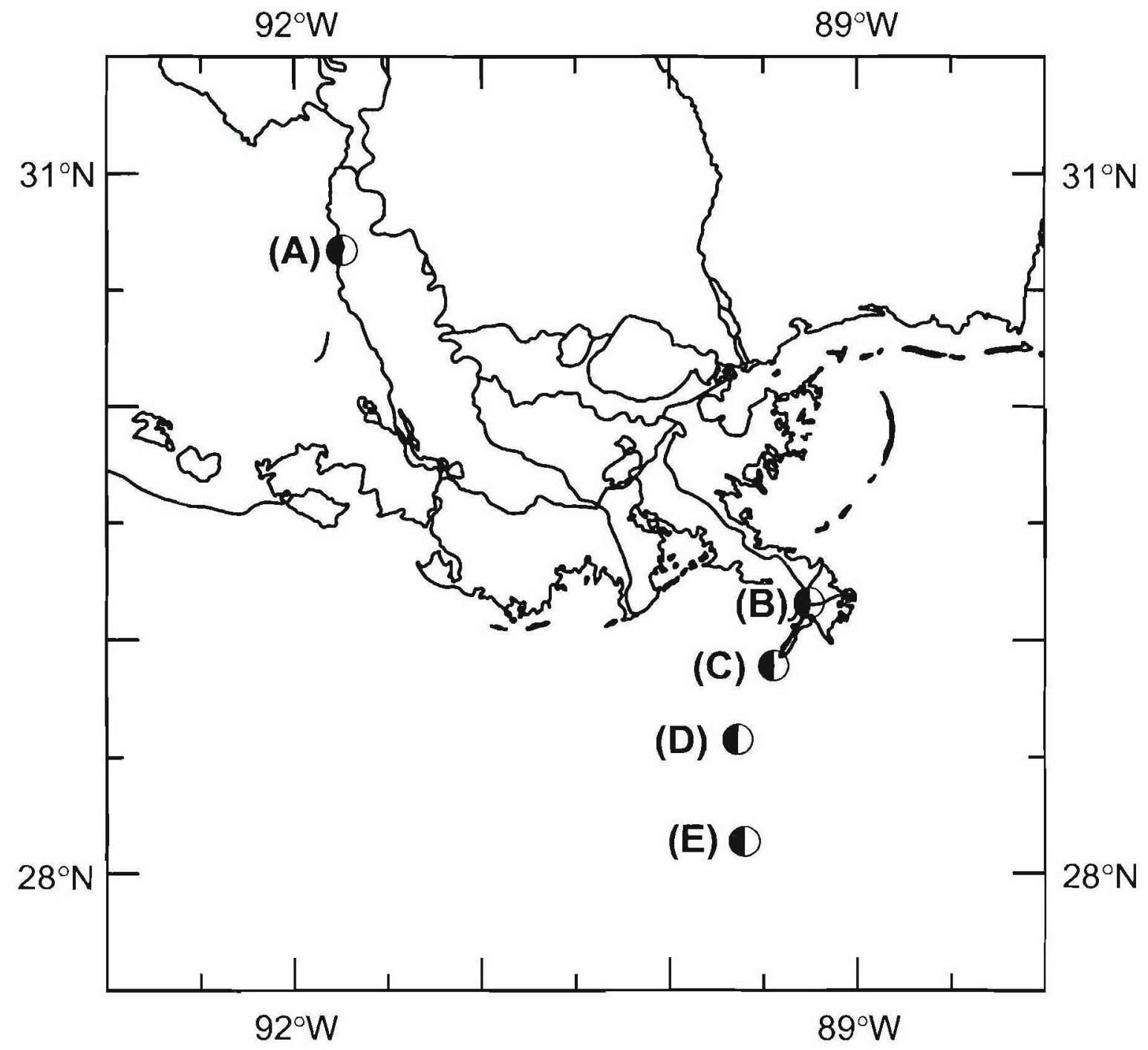

Figure 1. Sampling sites aboard the R/V Pelican. (A) Atchafalaya River. (B) Mississippi River. (C) Mixed Salinity. (D) Aged Plume. (E) Gulf of Mexico. 


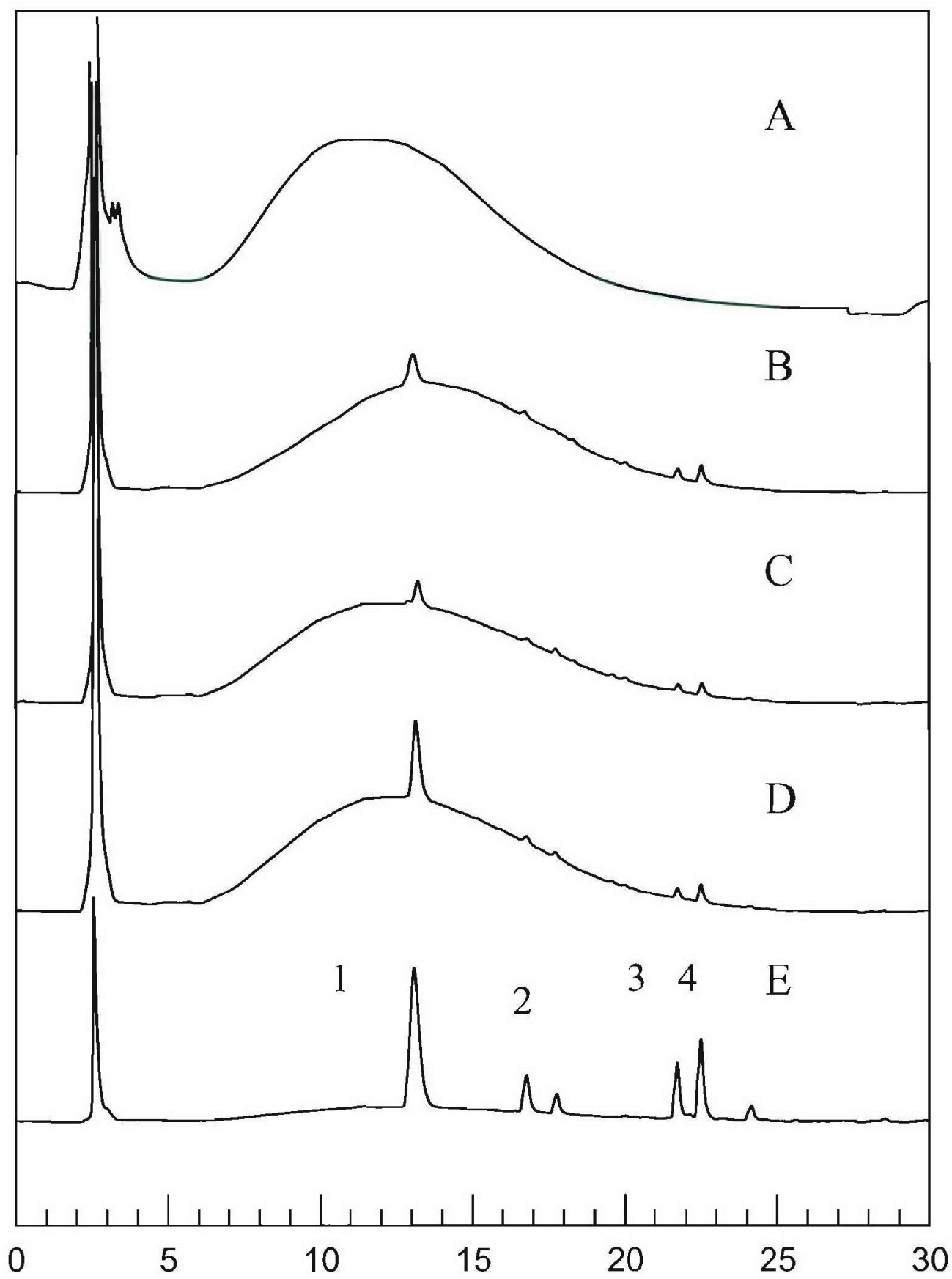

Figure 2. Chromatograms of the five Mississippi samples. From top to bottom: (A) Atchafalaya River. (B) Mississippi River. (C) Aged plume. (D) Mixed salinity. (E) Gulf of Mexico. 
We collected the four largest peaks (Unknowns 1-4, Fig. 2) in the Gulf of Mexico sample for identification by 'HNMR. Unknown peak 1 was identified as 2,4dichlorobenzoic acid (Fig. 3), with $\lambda_{\max }(\mathrm{MeOH}) 206$ and $228 \mathrm{~nm}$; retention time $14.8 \mathrm{~min}$ (gradient $1,15 \mathrm{~cm}$ column); ${ }^{1} \mathrm{HNMR}\left(\mathrm{CD}_{3} \mathrm{OD}\right) \mathrm{d} 7.45(1 \mathrm{H}, \mathrm{d}, J=8.37 \mathrm{~Hz}, \mathrm{H}-6), 7.42$ $(1 \mathrm{H}, \mathrm{d}, J=1.94 \mathrm{~Hz}, \mathrm{H}-3), 7.30(1 \mathrm{H}, \mathrm{dd}, J=8.37,1.94 \mathrm{~Hz})$ (Fig. 4): GC/MS of the methyl ester yields (m/z, \% rel. int.) 204(20), 173(100), 145(25), 109(25), 74(23). Co-injection of unknown A with authentic 2,4-dichlorobenzoic acid yielded one peak on two HPLC systems which separate 2,4-2,5-, and 3,4-dichlorobenzoic acid isomers. We also observed no change in the 'HNMR spectrum upon mixing of unknown A with authentic 2,4-dichlorobenzoic acid.<smiles>O=C(O)c1ccc(Cl)cc1Cl</smiles><smiles>O=C(O)c1cc(Cl)c(-c2ccc(Cl)cc2Cl)cc1Cl</smiles><smiles>O=C(O)c1ccc(-c2cc(Cl)c(Cl)cc2Cl)cc1Cl</smiles><smiles>O=C(O)c1cc(Cl)c(-c2ccc(Cl)cc2Cl)c(Cl)c1</smiles>

Figure 3. Structures and hypothetical structures of chlorinated aromatic acids isolated from seawater and algal cultures. 2,4-dichlorobenzoic acid (left) and possible substitution patterns for compounds $3,4 \mathrm{~A}$ and $4 \mathrm{~B}$ (left to right).

Unknown peak 2 had $U V \lambda_{\max }(\mathrm{MeOH})<210 \mathrm{~nm}$; retention time $17.7 \mathrm{~min}$ (gradient $1,15 \mathrm{~cm}$ column); ${ }^{\mathrm{H}} \mathrm{NMR}\left(\mathrm{CD}_{3} \mathrm{OD}, 400 \mathrm{MHz}\right) \delta 8.05(1 \mathrm{H}, \mathrm{d}, J=8.36 \mathrm{~Hz})$, $7.59(1 \mathrm{H}, \mathrm{d}, J=2.10 \mathrm{~Hz}), 7.45(1 \mathrm{H}, \mathrm{dd}, J=8.40,2.13 \mathrm{~Hz})($ Fig. 4). The 1 HNMR spectrum is similar to 2,4-dichlorobenzoic acid in the presence of a $2 \mathrm{~Hz}$ doublet, 2 and 8 $\mathrm{Hz}$ doublet of doublets and an $8 \mathrm{~Hz}$ doublet, but the spectrum does not correspond to the IHNMR spectrum of either 3,4-dichloro- or 2,5-dichloro-benzoic acids in DMSO. There was insufficient sample of unknown peak 2 for GC/MS analyses, and we therefore only make a preliminary assignment as a dichlorobenzoic acid. 

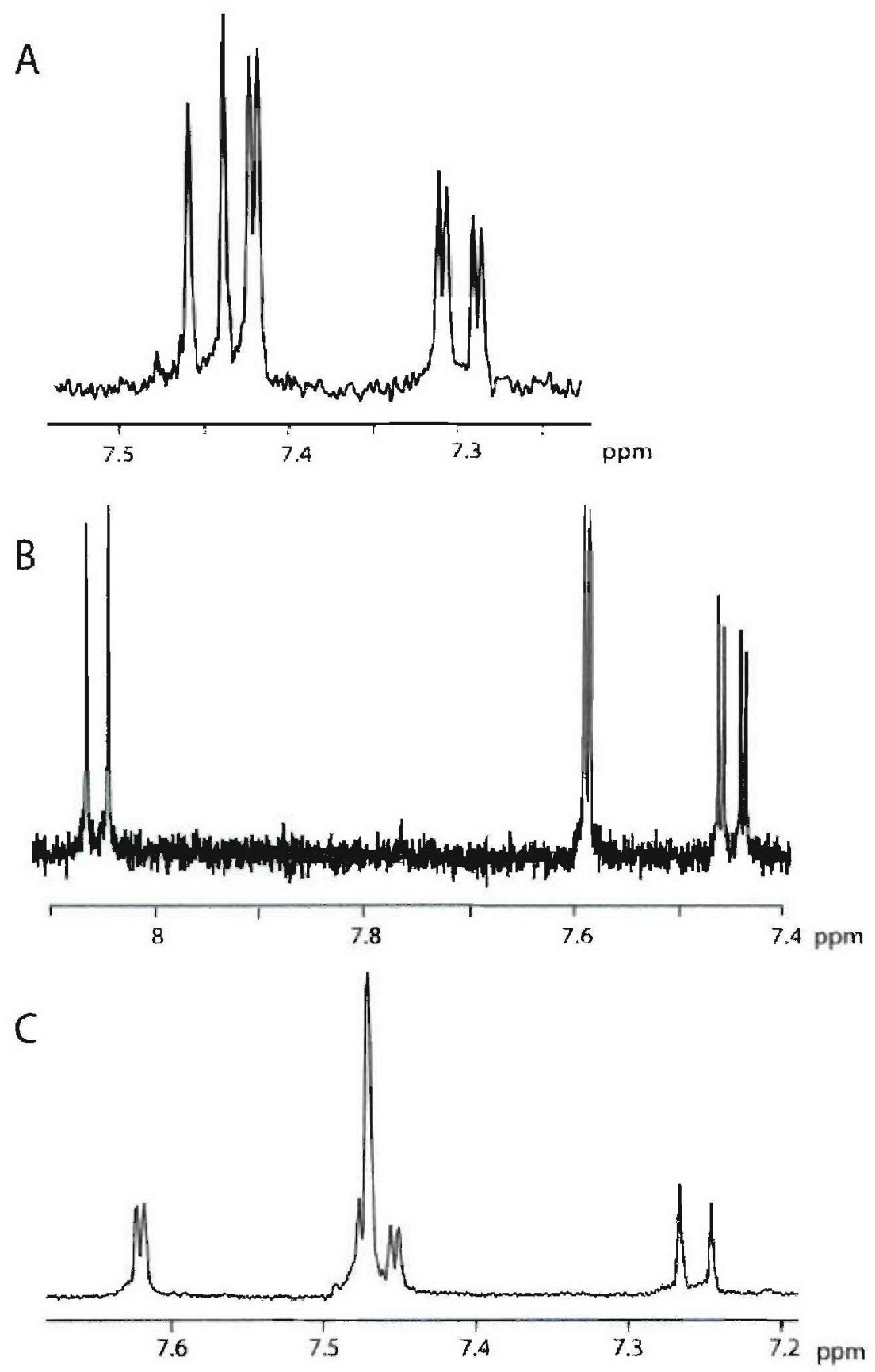

Figure 4. The $1 \mathrm{HNMR}$ (in $\mathrm{D}_{2} \mathrm{O}$ ) of (A) unknown peak 1 (2,4-dichloro-benzoic acid), (b) unknown peak 2, and (C) unknown peak 3 from the Gulf of Mexico. All chemical shifts are referenced to water at $4.8 \mathrm{ppm}$.

The ${ }^{1} \mathrm{HNMR}$ of unknown 3 had UV $\lambda_{\max }(\mathrm{MeOH})<210$; retention time $22.8 \mathrm{~min}$ (gradient 1, $15 \mathrm{~cm}$ column); ${ }^{1} \mathrm{H}$ NMR $\left(\mathrm{CD}_{3} \mathrm{OD}, 400 \mathrm{MHz}\right) \delta 7.62(1 \mathrm{H}, \mathrm{d}, J=1.94 \mathrm{~Hz})$, 
$7.47(2 \mathrm{H}, \mathrm{s}), 7.46(1 \mathrm{H}, \mathrm{dd}, J=8.37,1.94 \mathrm{~Hz}), 7.26(1 \mathrm{H}, \mathrm{d}, J=8.37 \mathrm{~Hz})(\mathrm{Fig} .6)$. The spectrum has much the same pattern as observed for seawater unknowns 1 and 2, with an $8 \mathrm{~Hz}$ coupled doublet, a 1.9 and $8 \mathrm{~Hz}$ coupled doublet of doublets, and a $1.9 \mathrm{~Hz}$ coupled doublet, but the chemical shifts of each proton had changed substantially. For unknown peaks 1 and 2, the $8 \mathrm{~Hz}$ doublet appears downfield of all other signals. For unknown peak 3 , the $8 \mathrm{~Hz}$ doublet appears upfield of all other signals. Unknown peak 3 was tentatively identified as a dichloro-(dichloro)-phenyl-benzoic acid. The coupling pattern suggests an arrangement of functional groups similar to probably 2-chloro-4-(3',4',6' or 3',5',6'-trichloro)-phenyl-benzoic acid (Fig.2). However, all such arrangements do not yield the appropriate symmetry to yield the para orientation inferred from the two proton singlet,. Insufficient material was available for $\mathrm{GC} / \mathrm{MS}$ and this assignment is only tentative.

Unknown 4 appeared to elute as a mixture of at least two, unresolved peaks and was purified by further separation into three major compounds using a $15 \mathrm{~cm} \mathrm{C-18}$ column, but eluted with $50 \mathrm{mM}$ ammonium acetate : acetonitrile (Fisher Scientific, HPLC grade) : methanol gradient at a flow rate of $1 \mathrm{~mL} / \mathrm{min}(70: 25: 5 ; 2.5 \mathrm{~min}) /(0: 70: 30 ; 12.5$ $\min ) /(0: 15: 85 ; 25 \mathrm{~min})$ (gradient 2, Fig. 5). Unknown peak 4B was identified as an isomer of tetrachloro-biphenyl carboxylic acid (Fig. 2) with $\lambda_{\max }(\mathrm{MeOH}) 211 \mathrm{~nm}$; ${ }^{1} \mathrm{HNMR}\left(\mathrm{CD}_{3} \mathrm{OD}\right) \delta 7.60(1 \mathrm{H}, \mathrm{d}, J=1.94 \mathrm{~Hz}), 7.57(1 \mathrm{H}, \mathrm{s}), 7.44(1 \mathrm{H}, \mathrm{dd}, J=8.37,1.94$ $\mathrm{Hz}), 7.38(1 \mathrm{H}, \mathrm{s}), 7.32(1 \mathrm{H}, \mathrm{d}, J=8.37 \mathrm{~Hz}$ ) (Fig. 6): GC/MS of the methyl ester yields (m/z, \% rel. int.) 350(35), 319(100), 254(60), 219(10), 184(35). Negative ion mode liquid chromatography/mass spectrometry of unknown peak 4B shows prominent molecular ions at $\mathrm{m} / \mathrm{z} 333\left({ }^{35} \mathrm{Cl}_{4} \mathrm{M}+\right.$; (observed abundance/theoretical abundance for $\mathrm{C}_{12}$, $\left.\left.\mathrm{H}_{6}, \mathrm{O}_{2}, \mathrm{C}_{14}\right) 79 / 78\right), 335\left({ }^{35} \mathrm{Cl}_{3}{ }^{37} \mathrm{Cl} \mathrm{M}+, 100 / 100\right), 337\left({ }^{35} \mathrm{Cl}_{2}{ }^{37} \mathrm{Cl}_{2} \mathrm{M}+; 47 / 48\right)$, and 339 $\left({ }^{35} \mathrm{Cl}^{37} \mathrm{Cl}_{3} \mathrm{M}+; 10 / 10\right)$, with a major ion cluster at $\mathrm{m} / \mathrm{z} 291$ from loss of carbon dioxide, confirming the presence of a carboxylic acid. Further evidence comes from the mass spectrum of the methylated derivative, which displays prominent molecular ions at $\mathrm{m} / \mathrm{z}$ $348\left({ }^{35} \mathrm{Cl}_{4} \mathrm{M}+\right), 350\left({ }^{35} \mathrm{Cl}_{3}{ }^{37} \mathrm{Cl} \mathrm{M}+\right), 352\left({ }^{35} \mathrm{Cl}_{2}{ }^{37} \mathrm{Cl}_{2} \mathrm{M}+\right)$, and $354\left({ }^{35} \mathrm{Cl}^{37} \mathrm{Cl}_{3} \mathrm{M}+\right)$, and major ion clusters at m/z $317\left(-\mathrm{OCH}_{3}\right), 254\left(-\mathrm{C}_{2} \mathrm{O}_{2} \mathrm{ClH}_{3}\right), 219\left(-\mathrm{C}_{2} \mathrm{O}_{2} \mathrm{Cl}_{2} \mathrm{H}_{3}\right), 184(-$ $\mathrm{C}_{2} \mathrm{O}_{2} \mathrm{Cl}_{3} \mathrm{H}_{3}$ ), as well as ions with $\mathrm{m} / \mathrm{z}<184$ resulting from fragmentation of the biphenyl ring. From the lack of coupling between the two protons at 7.57 and $7.38 \mathrm{ppm}$ on the 
trichlorophenyl ring we infer these protons are in a para orientation, suggesting a 3', 4', $6^{\prime}$ - or 2',4',5'-substitution pattern. Further, the upfield shift in the ortho coupled doublet to $7.32 \mathrm{ppm}$ is most similar to NMR spectra of 3,4-disubstituted benzoic acids. Our data support a structural assignment of unknown peak $4 \mathrm{~B}$ as either 3-chloro-4-(2',4',5'trichlorophenyl)-benzoic acid or 4-chloro-3-(2, $4^{\prime}, 5^{\prime}$-trichlorophenyl)-benzoic acid. We know of no previous reports of tetrachloro-biphenyl carboxylic acids in the environment, and no authentic standards of these compounds are presently available. Therefore, the specific isomer of tetrachloro-biphenyl carboxylic acid in unknown peak $4 \mathrm{~B}$ cannot be assigned at this time.

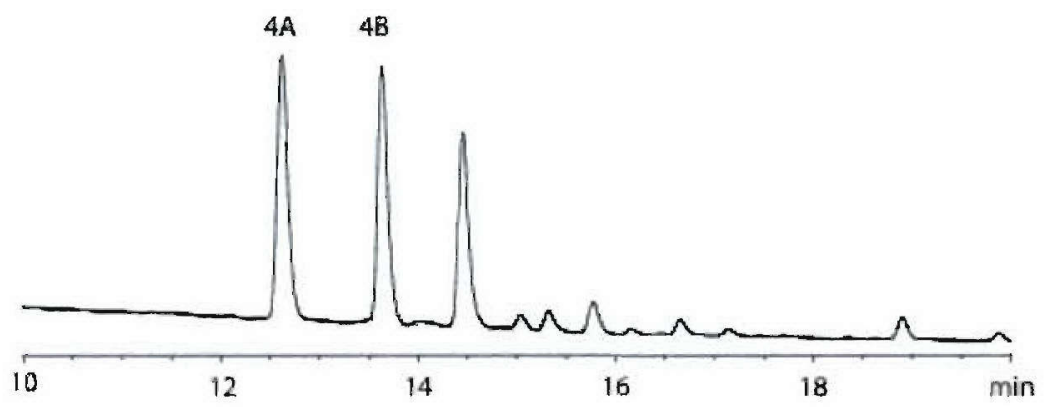

Figure 5. Separation of seawater unknown peak 4 by reverse phase HPLC using an ammonium acetate, methanol and acetonitrile gradient (gradient 2) and a C-18 column.

Seawater unknown 4A was separated from unknown 4B by reverse phase HPLC using a mixture of water, acetonitrile and methanol as described above (Fig. 5). The similar chromatographic properties of unknown $4 \mathrm{~A}$ to $4 \mathrm{~B}$ suggests a close structural similarity, which was confirmed by spectral analyses. Purified unknown peak 4A had $\lambda_{\max }(\mathrm{MeOH}) 210 \mathrm{~nm} ;{ }^{\prime} \mathrm{HNMR}\left(\mathrm{CD}_{3} \mathrm{OD}\right) \delta 7.53(1 \mathrm{H}, \mathrm{d}, J=1.93 \mathrm{~Hz}), 7.48(2 \mathrm{H}, \mathrm{d}, J=$ $1.93 \mathrm{~Hz}), 7.46(1 \mathrm{H}, \mathrm{d}, J=8.37), 7.34(1 \mathrm{H}, \mathrm{dd}, J=8.37,1.94 \mathrm{~Hz}), 7.20(1 \mathrm{H}, \mathrm{d}, J=1.94$ Hz) (Fig. 6). GC/MS of the methyl ester yields (m/z, \% rel. int.) 350(50), 319(100), 254(55), 219(15),184(30). Unknown peak 4A is almost certainly a second isomer of tetrachloro-biphenyl carboxylic acid. We observe meta coupling of $1.9 \mathrm{~Hz}$ between protons on the trichlorophenyl substituent, suggesting $3^{\prime}, 5^{\prime}, 6^{\prime}-$ or $2^{\prime}, 4^{\prime}, 6^{\prime}$ chlorination. 
The NMR data, by analogy with NMR data for 2,4-dichlorobenzoic acid suggests this compound is either 2-chloro-4-(3',5',6'- or 2', 4',6' )-trichlorophenyl)-benzoic acid or 4chloro-( $3^{\prime}, 5^{\prime}, 6^{\prime}$ - or $\left.2^{\prime}, 4^{\prime}, 6^{\prime}\right)$-trichlorophenyl)-benzoic acid (Fig. 2). Our assessment is preliminary, and full assignment must await comparison to authentic standards.

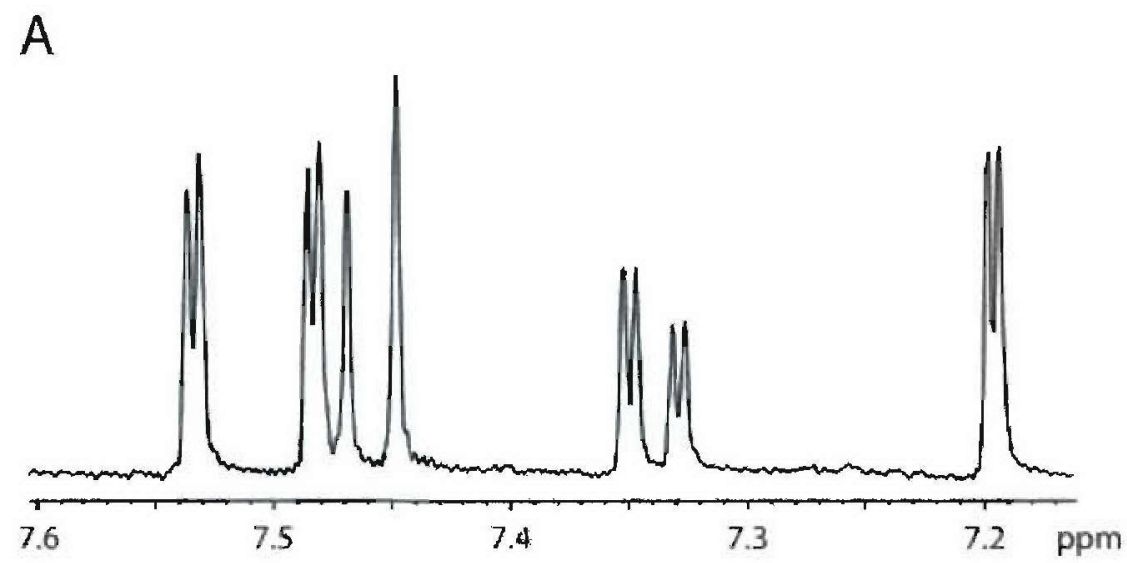

B

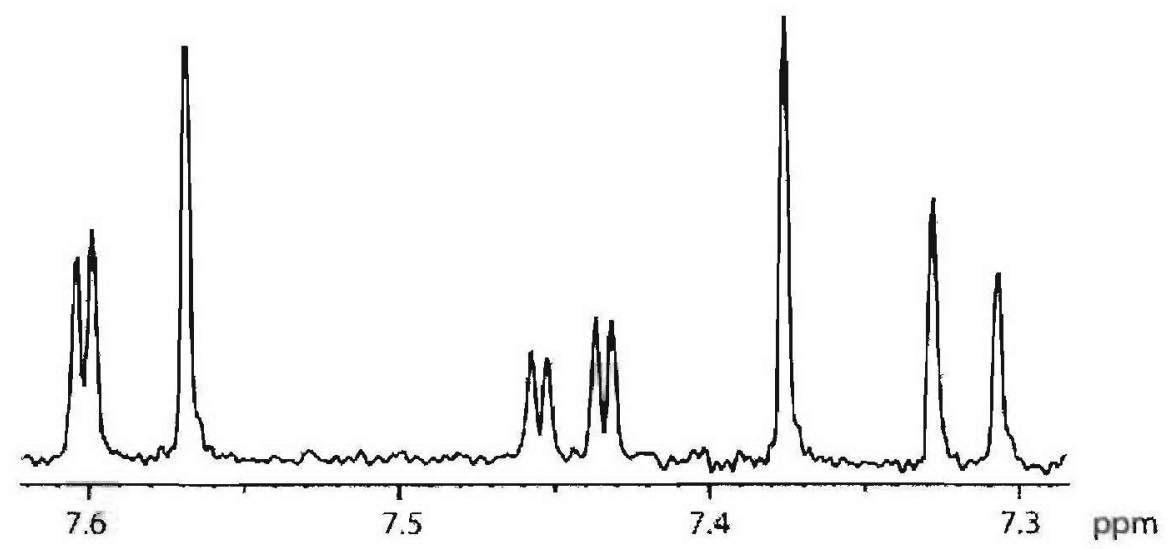

Figure 6. Proton NMR spectra (in $\mathrm{D}_{2} \mathrm{O}$ ) of unknown peaks 4A (top) and 4B (bottom) from the North Pacific Ocean sample. The spectra are referenced to water at $4.8 \mathrm{ppm}$.

We also isolated CDOM from oligotrophic marine sites in the North Pacific Ocean near Hawaii and the North Atlantic Ocean at the Bermuda Biological Station. Coastal seawater was further sampled sampled from Woods Hole, MA (Table 1). Ultraviolet-visible spectra of the methanol extracts for all samples show a logarithmic- 
like decrease in absorption with increasing wavelength, similar to whole seawater absorption spectra $(4, I l)$.

Table 1. Sample location, depth, volume and CDOM extraction details.

$\begin{array}{lcclcc}\text { Sample } & \text { Depth }(\mathrm{m}) & \mathrm{Vol}(\mathrm{L}) & \text { Lat/Long } & \text { resin }(\mathrm{g}) & \text { flow }(\mathrm{mL} / \mathrm{min}) \\ \text { Woods Hole } & 3 & 760 & 41^{\circ} 31^{\prime} \mathrm{N}, 70^{\circ} 40^{\prime} \mathrm{W} & 50 & 60 \\ \text { Bermuda } & 3 & 400 & 38^{\circ} 20^{\prime} \mathrm{N}, 64^{\circ} 48^{\prime} \mathrm{W} & 50 & 60 \\ \text { North Pacific } & 3 & 40 & 24^{\circ} 25^{\prime} \mathrm{N}, 156^{\circ} 18^{\prime} \mathrm{W} & 20 & 20 \\ \text { North Pacific } & 1800 & 70 & 24^{\circ} 25^{\prime} \mathrm{N}, 156^{\circ} 18^{\prime} \mathrm{W} & 20 & 20\end{array}$

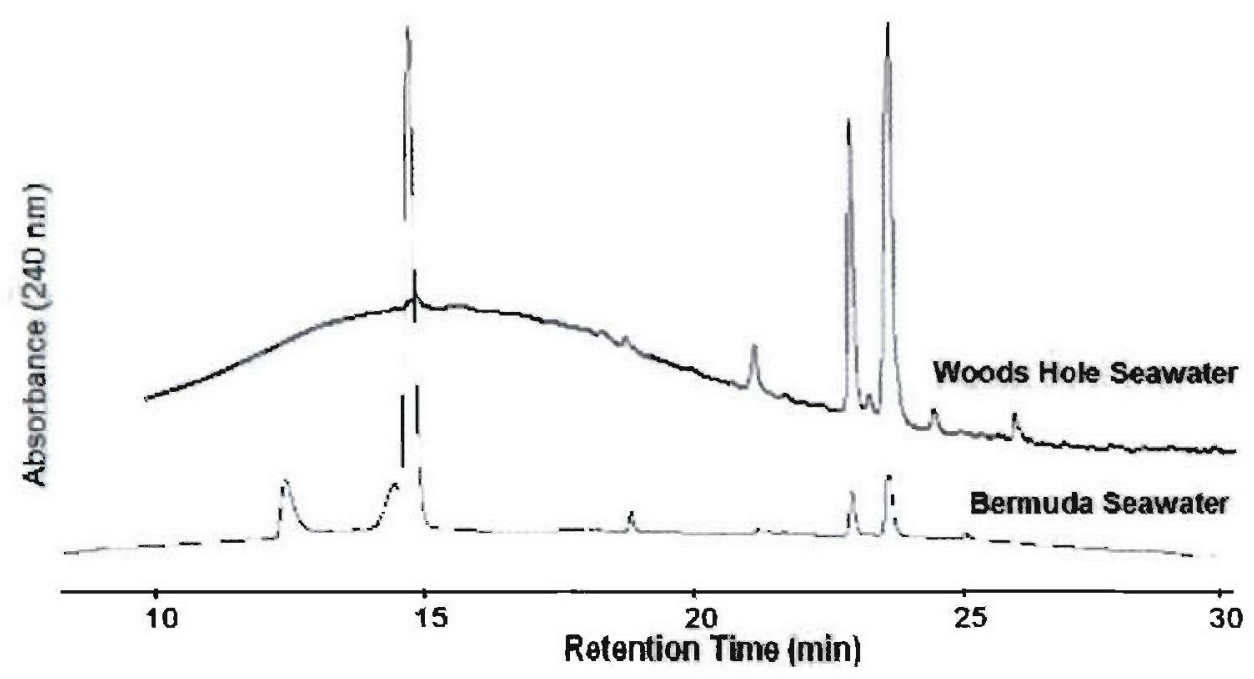

Figure 7. HPLC trace of CDOM (240 nm) in Wood Hole surface seawater and Bermuda surface seawater sampled by adsorption onto $\mathrm{C}_{18}$ resin. The Woods Hole sample displays a large hump of adsorption from unresolved complex CDOM material. Superimposed on the hump are chlorinated aromatic acids. The Bermuda seawater sample has chlorinated aromatic acids as its major CDOM components.

Using HPLC we characterized the CDOM mixture in each of these samples. Samples from Bermuda and the North Pacific Ocean have only small amounts of unresolved $\mathrm{CDOM}$, while the sample of coastal seawater from Woods Hole clearly shows 
the presence of terrestrially derived humic substances as inferred from the complex mixture of CDOM components (Figs. 7 and 8). Over 90 components with adsorption maxima between 240-400 nm were separated in samples from the North Pacific Ocean and Woods Hole. All components display strong absorption bands in the ultraviolet and near ultraviolet (Fig. 9). Further separation of some fractions show the presence of multiple co-eluting compounds, at least some of which were found to be structurally related to chlorinated benzoic acids and biphenyl carboxylic acids previously identified in Gulf of Mexico seawater. For example, the major components the North Pacific surface water sample were tetrachloro-biphenyl carboxylic acids, while the major component in Sargasso seawater was 2,4-dichlorobenzoic acid.

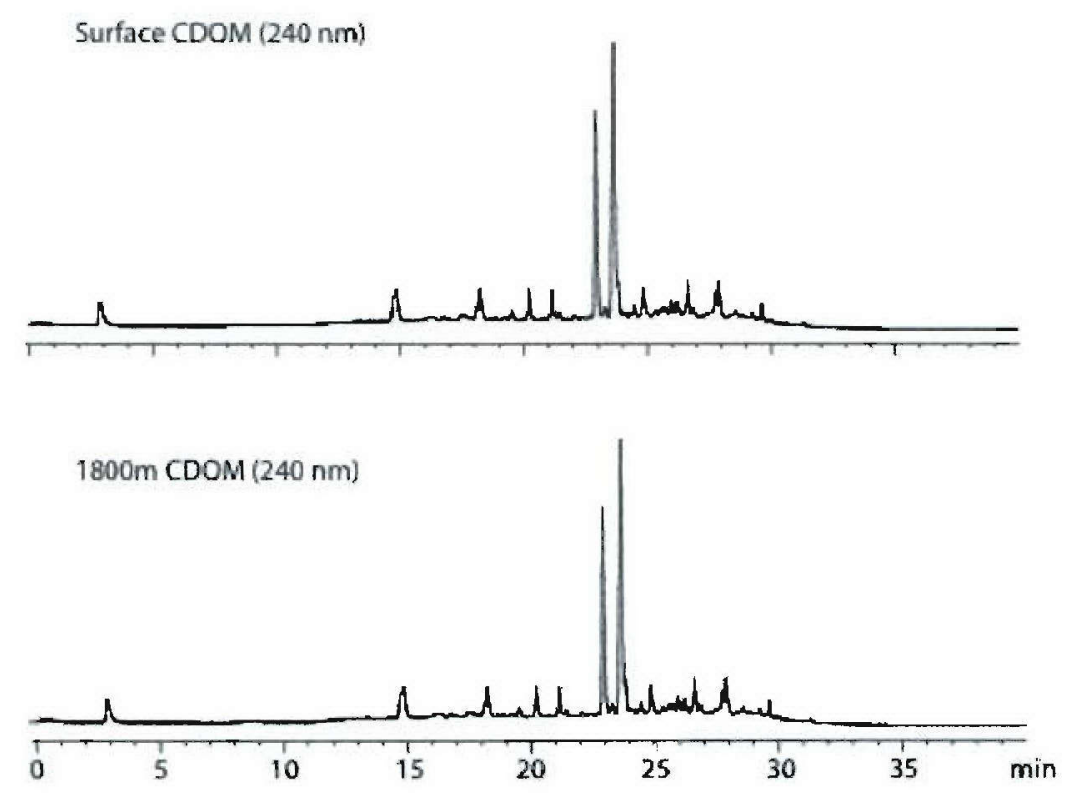

Figure 8. High pressure liquid chromatograms of CDOM components from the North Pacific Ocean at $3 \mathrm{~m}$ (top) and $1800 \mathrm{~m}$ (bottom). The chromatograms are identical and show 2,4-dichlorobenzoic acid and TCBCAs are major components as found in Gulf or Mexico can Sargasso Sea water samples. 


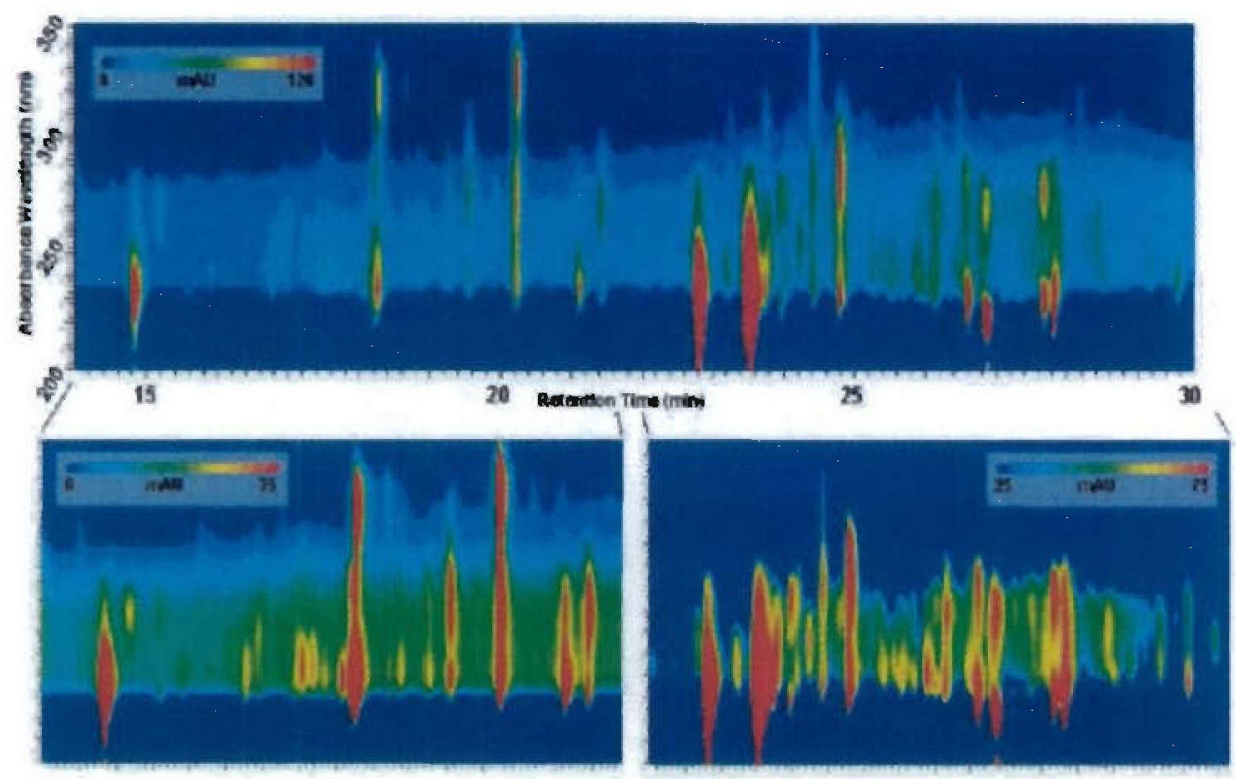

Expanded Regions

Fig. 9 Absorbance plot from 200-350 nm of CDOM in North pacific surface seawater (top) with expansions of the 14-22min and 23-30 min regions between 200-300 nm.

Proton nuclear magnetic resonance ( $\left.{ }^{1} \mathrm{HNMR}\right)$ spectra of the total methanol extracts are characterized by complex and unresolved resonance between 7-8 ppm, and show that at a major portion of CDOM adsorption arises from substituted aromatic compounds (Fig. 10). The complexity of NMR spectra is related to the complexity of the CDOM mixture separated by HPLC. Samples with complex mixtures of CDOM components show much greater complexity in the $7-8$ ppm region of the ${ }^{1}$ HNMR spectrum. Samples from the Pacific and Atlantic Oceans have the same major components by HPLC, which we purified for for structural characterization.

We quantified the amount of 2,4-dichlorobenzoic acid and tetrachloro-biphenyl carboxylic acids in our sample by calibrating our HPLC system with benzoic acid and adjusting for differences in molecular weight (Table 2). Our quantification assumes differences in the molar extinction of benzoic acid and our chlorinated biphenyl carboxylic acids are small. Values for 2,4-dichlorobenzoic acid (2,4-DCBA) range from almost not detectable in our Woods Hole seawater sample $(<0.1 \mu \mathrm{g} / \mathrm{L})$, to $0.4 \mu \mathrm{g} / \mathrm{L}$ in Pacific surface water, to $7.5 \mu \mathrm{g} / \mathrm{L}$ in Woods Hole Coastal seawater. Likewise, we 
observe variable concentrations of total tetrachloro-biphenyl carboxylic acids (TCBCAs) ranging from $1 \mu \mathrm{g} / \mathrm{L}$ in Woods Hole Seawater to $3.8 \mu \mathrm{g} / \mathrm{L}$ in the Pacific Ocean. We collected very different sized samples from each of our sites, using slightly different column aspect ratios and amounts of $\mathrm{C}_{18}$ hydrophobic resin. Therefore, some of the observed differences in concentration may result from differences in extraction efficiencies.

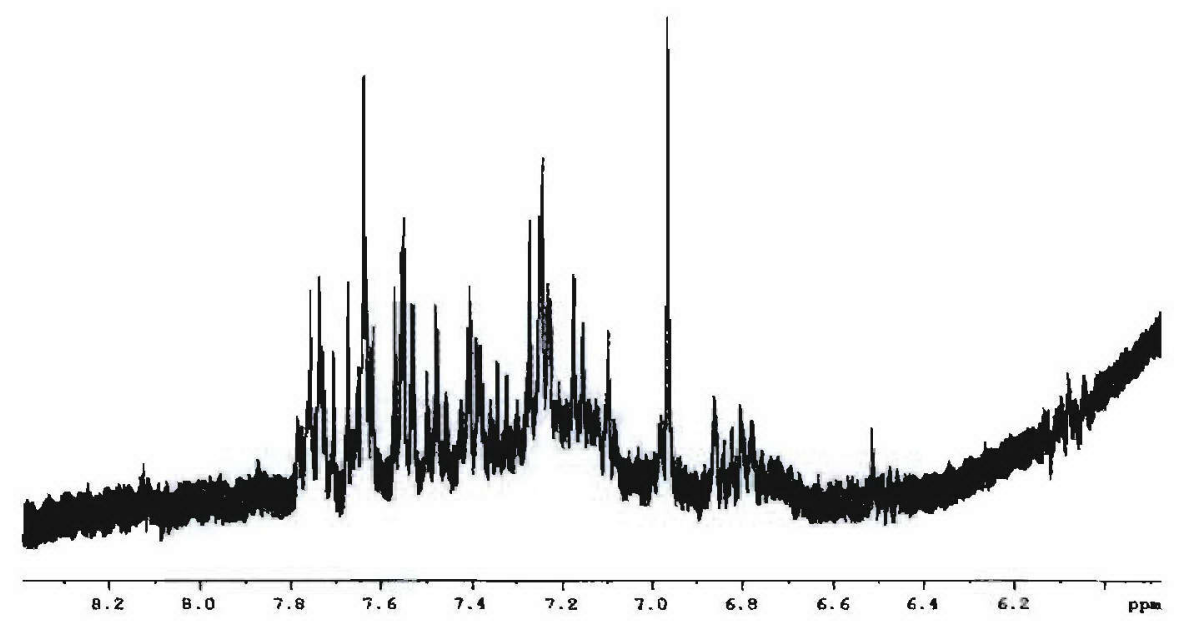

Figure 10. 'HNMR spectrum (in $\mathrm{D}_{2} \mathrm{O}$ ) of North Pacific surface water sample prior to HPLC separation. The spectrum shows a complex mixture of substituted aromatic acids some of which were purified and structurally characterized as chlorinated aromatic acids.

Table 2. Concentrations $(\mu \mathrm{g} / \mathrm{l})$ of dissolved chlorinated aromatic acids in seawater.

Sample

Pacific Ocean, $3 \mathrm{~m}$

Pacific Ocean, 1800m

Bermuda, 3m

Woods Hole, $3 \mathrm{~m}$
2,4-DCBA

$0.4^{*}$

0.9

7.5

\section{Peak 3}

1.1

1.4

0.4

0.3
Peak 4a

0.9

1.2

$0.8^{*}$
Peak 4B

0.9

1.2

0.3

0.4

Chlorinated aromatic acids contribute only a portion of the total dissolved organic carbon in seawater, but their contribution to CDOM absorption in the near UV is significant, particularly in open ocean waters. High concentrations of 2,4-DCBA and TCBCAs were measured in both surface and deep water samples, with total 
concentrations $(2,4-\mathrm{DCBA}+\Sigma \mathrm{TCBCAs})$ ranging from $1-9 \mu \mathrm{g} / \mathrm{l}$ (Table 2$)$. Using the concentration and extinction coefficient of 2,4-DCBA we calculate that this compound alone contributes $2 \%$ of the total CDOM absorption at $280 \mathrm{~nm}$ (UV-A/UV-B) in our Bermuda sample extracts. The NMR spectra of whole sample extracts (Fig. 10) show that 2,4-DCBA $+\Sigma$ TCBCAs are only some of the substituted aromatic compounds present in seawater. The contribution of substituted aromatic compounds to CDOM absorption in the ultraviolet is therefore several times higher than the contribution from 2,4-DCBA $+\Sigma T C B C A s$ alone.

Of the compounds identified in this study, only 2,4-DCBA is a known anthropogenic product. This compound is used commercially in the production of pharmaceuticals, and is an impurity in some herbicides. Low concentrations of 2,4DCBA measured in groundwater, rivers and lakes, have been attributed to anthropogenic contamination, as well as biological and photochemical degradation of anthropogenically produced polychlorinated biphenyls (PCBs) (22-26). However, 2,4-DCBA in some pristine waters has been attributed to direct biological production (27). Tetrachlorinated biphenyl carboxylic acids have not been previously reported as products of either anthropogenic production, or the degradation of PCBs.

Assuming the concentration of $\Sigma$ TCBCAs averages $1 \mu \mathrm{g} / \mathrm{l}$ (Table 1) for the upper $1800 \mathrm{~m}$ of the global ocean, we calculate a global ocean inventory of approximately 300 MT for these compounds, over two orders of magnitude higher than the estimated 0.6-1.5 MT of PCBs that have been produced by commercial synthesis (28). Most of the global PCB inventory resides in terrestrial reservoirs, and estimates suggest only a few percent of anthropogenic PCB production has been transported the ocean. The global inventory of TCBCAs is therefore $>10,000$ times the total marine inventory of PCBs.

Our estimate of the marine inventory for chlorinated aromatic acids is probably conservative, as either a higher average concentration (Table 2) or the occurrence of chlorinated aromatic acids at depths $>1800 \mathrm{~m}$ will substantially increase the amount of these compounds sequestered in the ocean. Concentrations of PCBs in heavily impacted coastal waters are $<1 \mathrm{ng} / \mathrm{l}$, and fall rapidly with depth. PCBs have been reported to depths of $1500 \mathrm{~m}$ in the coastal ocean, but concentrations below the mixed layer are only $1-10 \mathrm{pg} / \mathrm{l}(29)$. We further note that only a few, specific tetrachlorinated biphenyl 
carboxylic acid isomers are found in our samples, while many of the products expected from carboxylation of the most common PCB congeners in the environment are absent. Anthropogenic inputs of 2,4-DCBA and partial degradation of anthropogenically produced PCBs may be minor sources for chlorinated aromatic acids in seawater, but they cannot account for the observed distribution and concentration of 2,4-DCBA and TCBCAs in our samples. The distribution of chlorinated aromatic acids in our samples, their global marine inventory and presence of only specific chlorinated aromatic acids suggest these compounds are produced in-situ by marine microbes.

A wide variety of organochlorine natural products have been identified in marine organisms, including simple chlorinated aromatic compounds (30,3I). Halogenated organic compounds are thought to serve as chemical defense agents in marcofauna and flora, but halogenated organic compounds are also common in microorganisms, where their role is unclear (30). We know of no reports that describe naturally occurring polychlorinated biphenyl-like compounds in marine organisms. However, a series of recent papers have described a suite of halogenated dimethyl bipyrroles that are widely found in marine biological samples, including tissue samples of marine mammals and birds (32). Halogenated dimethyl bipyrroles have not been measured in seawater, but they do occur even in low trophic levels in marine food webs, and are most likely produced by marine plankton or bacteria (33). The tetrachloro-biphenyl carboxylic acids reported here are also widely distributed in the marine environment, and the large global inventory suggests they are most likely produced by marine microorganisms.

\section{Characterization of CDOM in laboratory cultures of marine algae}

To further investigate the sources of the 2,4-DCBA and TCBCAs we extracted CDOM from laboratory cultures of marine algae. Cultures were grown using seawater collected near the Woods Hole Oceanographic Institution. Water was pumped through a $0.2 \mu \mathrm{m}$ Polycap ${ }^{\mathrm{TM}} \mathrm{TC}$ polyethersulfone filter to remove any particulate matter, and collected in a 200L fluorinated high-density polyethylene (HDPE) barrel. The sample was acidified to a pH of 2 using approximately $7-14 \mathrm{~mL}$ concentrated hydrochloric acid, and DCAs/TCBCAs recovered by slowly pumping the sample through a $4.8 \mathrm{~cm}$ diameter 
glass column packed with approximately $50 \mathrm{~g}$ of clean $\mathrm{C}_{18}$ functionalized silica gel (Aldrich) into an 18L fluorinated HDPE carboys.

The filtered, extracted seawater was returned to a $\mathrm{pH}$ of 8 using $4 \mathrm{M}$ sodium hydroxide. We prepared $\mathrm{f} / 2$ media according to the recipe described by the ProvasoliGuillard National Center for Culture of Marine Phytoplankton (CCMP). The media was autoclaved (30 min sterilization/30 min exhaust) and cooled for 24 hours. Emiliania huxleyi (CCMP374) and Isochrysis galbana (CCMP1323) cultures were obtained from CCMP and inoculated, under aseptic conditions, into $25 \mathrm{~mL}$ media using $10 \mathrm{~mL}$ of concentrated CCMP cultures. Cultures were kept in an incubator at $18^{\circ} \mathrm{C}$ on a $13 / 11$ hour day/night cycle. Cell density was monitored as often as possible. When maximum cell density was reached, the cultures were inoculated into $1 \mathrm{~L}$ flask, then subsequently into $18 \mathrm{~L}$ glass carboys. When maximum cell density was reached in the $18 \mathrm{~L}$ cultures they were filtered through a $0.2 \mu \mathrm{m}$ Polycap ${ }^{\mathrm{TM}} \mathrm{TC}$ polyethersulfone filter to remove algae and bacteria and acidified to a $\mathrm{pH}$ of 2 with concentrated $\mathrm{HCl}$. At this time a small aliquot was removed from the culture for UV-Vis analysis. The water was again passed through a column packed with clean functionalized $\mathrm{C}_{18}$ silica gel to collect CDOM produced by the cultures.

CDOM was eluted from the column in three fractions. An $80 \mathrm{~mL}$ Q-water ( $\mathrm{pH} 2$ ) fraction removed most excess salt, and a $100 \mathrm{~mL}$ methanol fraction removed the majority of CDOM and usually appeared clear yellow in color. A final $100 \mathrm{~mL}$ fraction of $11.8 \mathrm{M}$ ammonium hydroxide was collected which removed any CDOM remaining on the column. The methanol fraction was evaporated to dryness, dissolved in methanol and residual salts removed by centrifugation. The sample was dissolved in $1 \mathrm{~mL}$ of methanol in preparation for HPLC analyses. A blank was performed by processing a $20 \mathrm{~L}$ sample as above with the omission of culture inoculation and growth. This control was made to ensure processing methods were not responsible for CDOM in the cultures. CDOM was analyzed by HPLC using the method described above for seawater samples.

The HPLC chromatograms for both the E. hwxleyi is presented in Figure 11. CDOM from each culture was collected in six fractions. HPLC fractions 2, 4 and 5 , which likely contained chlorinated aromatic acids, were further analyzed by ${ }^{1}$ HNMR spectroscopy (Figs. 12 and 13). The ${ }^{1} \mathrm{HNMR}$ of fraction 2 from each culture displayed 
signals at $\delta 7.39 \mathrm{ppm}(1 \mathrm{H}, \mathrm{d}, J=.8 .26 \mathrm{~Hz}), 7.35(1 \mathrm{H}, \mathrm{d}, J=1.90 \mathrm{~Hz})$, and $7.22(1 \mathrm{H}, \mathrm{dd}$, $J=8.33,2.04 \mathrm{~Hz}$ ). On the basis of HPLC retention times and ${ }^{1}$ HNMR spectra of these fractions we identified fraction 2 as 2,4-dichlorobenzoic acid, previously identified in all seawater samples. The ${ }^{1} \mathrm{HNMR}$ spectrum of fraction 4 in $\mathrm{CD}_{3} \mathrm{OD}$ had $87.55(1 \mathrm{H}, \mathrm{d}, \mathrm{J}=$ $1.98 \mathrm{~Hz}), 7.42(2 \mathrm{H}, \mathrm{d} 1.83), 7.41(1 \mathrm{H}, \mathrm{dd}, \mathrm{J}=8.77,2.19 \mathrm{~Hz}) 7.20(1 \mathrm{H}, \mathrm{dd}, \mathrm{J}=8.26)$ and was nearly identical to the ${ }^{1}$ HNMR spectrum of unknown peak 3 isolated from seawater. Fraction culture fraction 4 had a two proton doublet at $(7.42 \mathrm{ppm})$ in place of the two proton singlet at $7.47 \mathrm{ppm}$ observed for the seawater unknown peak 3 . The difference is due to the meta-vs para substitution of the protons on the TCBCA (Fig. 2).

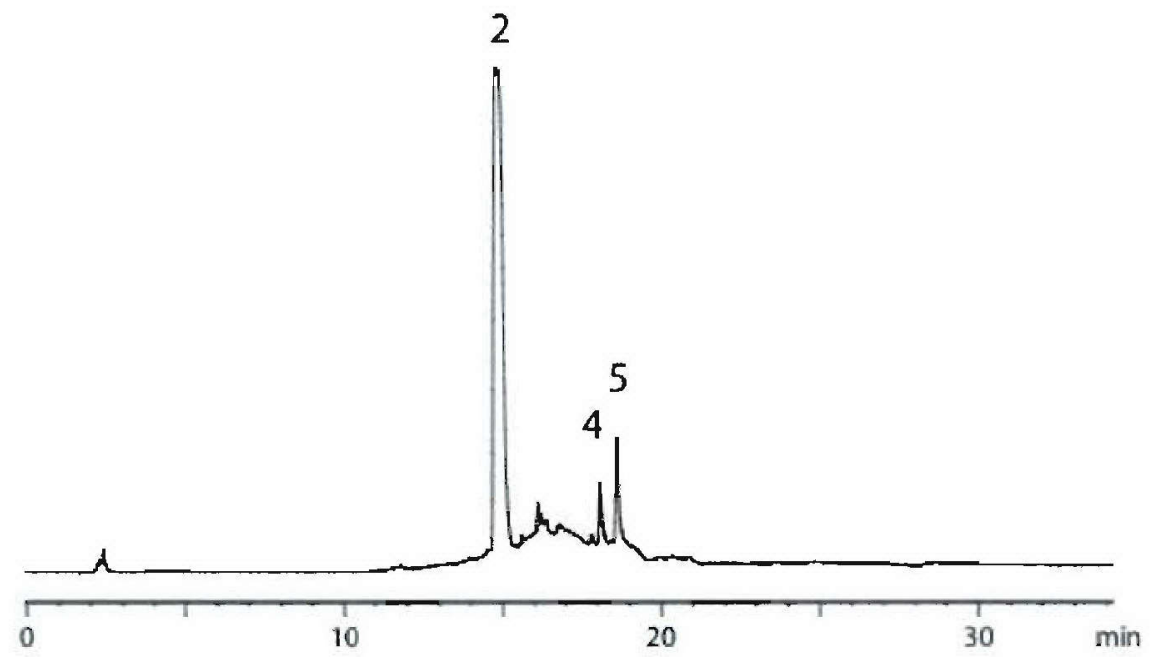

Figure 11. High pressure liquid chromatogram at $240 \mathrm{~nm}$ of CDOM in spent culture media from E.huxleyi. The major compound at $15 \mathrm{~min}$ was identified as $2,4-$ dichlorobenzoic acid.

Culture fraction 5 was isolated by HPLC using ammonium acetate and methanol only, analogous to unknown peak 4 in the seawater analyses. Although the equivalent fraction from seawater (seawater unknown 4) can be further separated into at least three distinct compounds by HPLC using an ammonium acetate, methanol, water gradient, no additional separation of culture fraction 5 was made. The ${ }^{\mathrm{H}} \mathrm{HNMR}$ spectra of culture fractions 5 are complex with $\delta\left(\mathrm{MD}_{3} \mathrm{OD}\right) 7.72 \mathrm{ppm}(\mathrm{d}, 7.98 \mathrm{~Hz}), 7.54(\mathrm{~d}, 2.05 \mathrm{~Hz}), 7.5$ (s), $7.46(2.19 \mathrm{~Hz}), 7.42(\mathrm{~s}), 7.41(\mathrm{~d}, 1.90 \mathrm{~Hz}), 7.40(2 \mathrm{H}$ ?, s), 7.39 (d, 2Hz), 7.32 (s), 7.29 
A
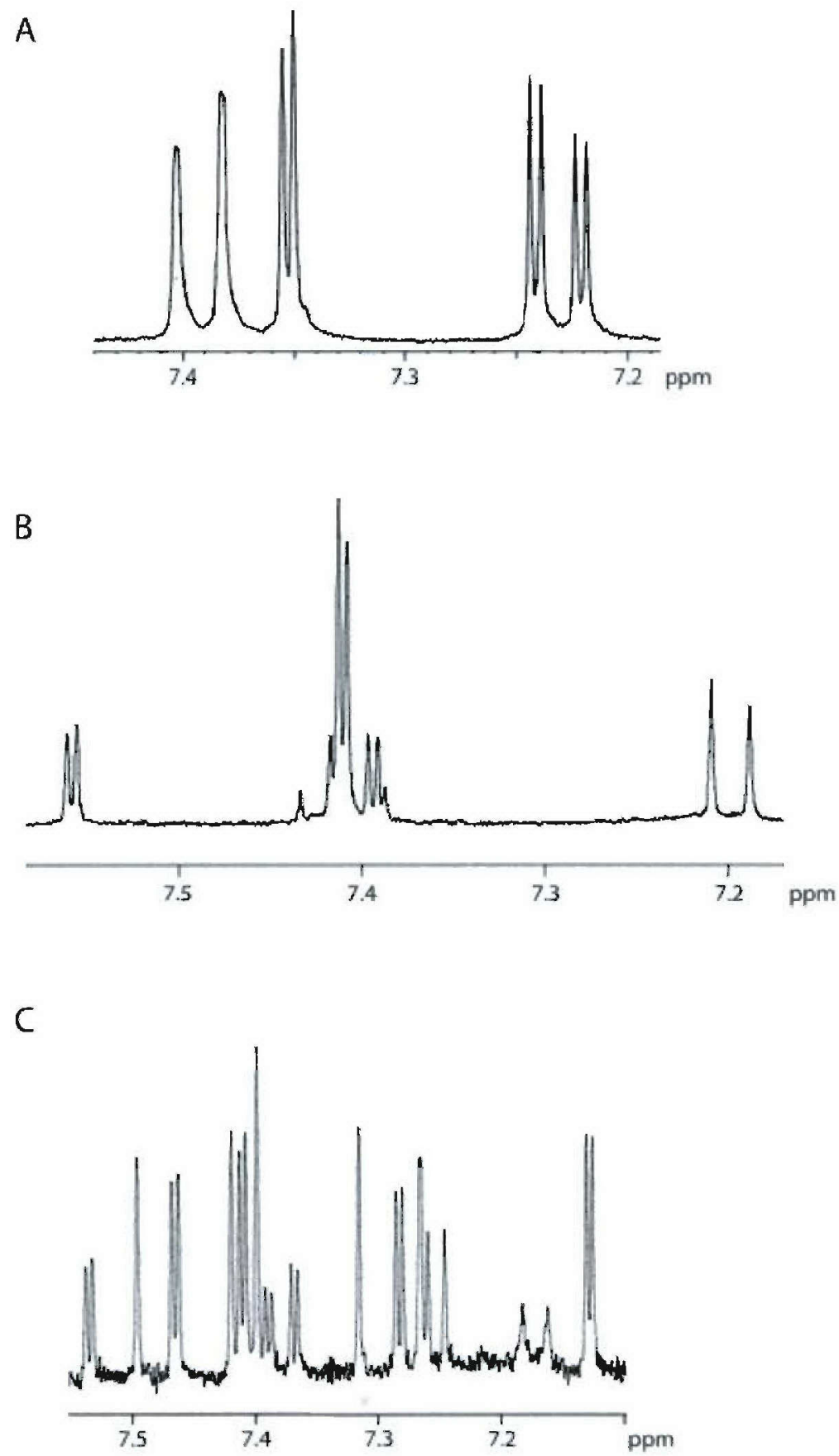

Figure 12. ${ }^{1} \mathrm{HNMR}$ of major CDOM components in E. huxleyi. Major CDOM components were identified as chlorinated aromatic acids by comparison with compounds isolated from seawater. (A) 2,4-dichlorobenzoic acid, (B) tetrachloro-bipenyl carboxylic acid, and (C) a mixture of two tetrachloro-biphenyl carboxylic acids. 

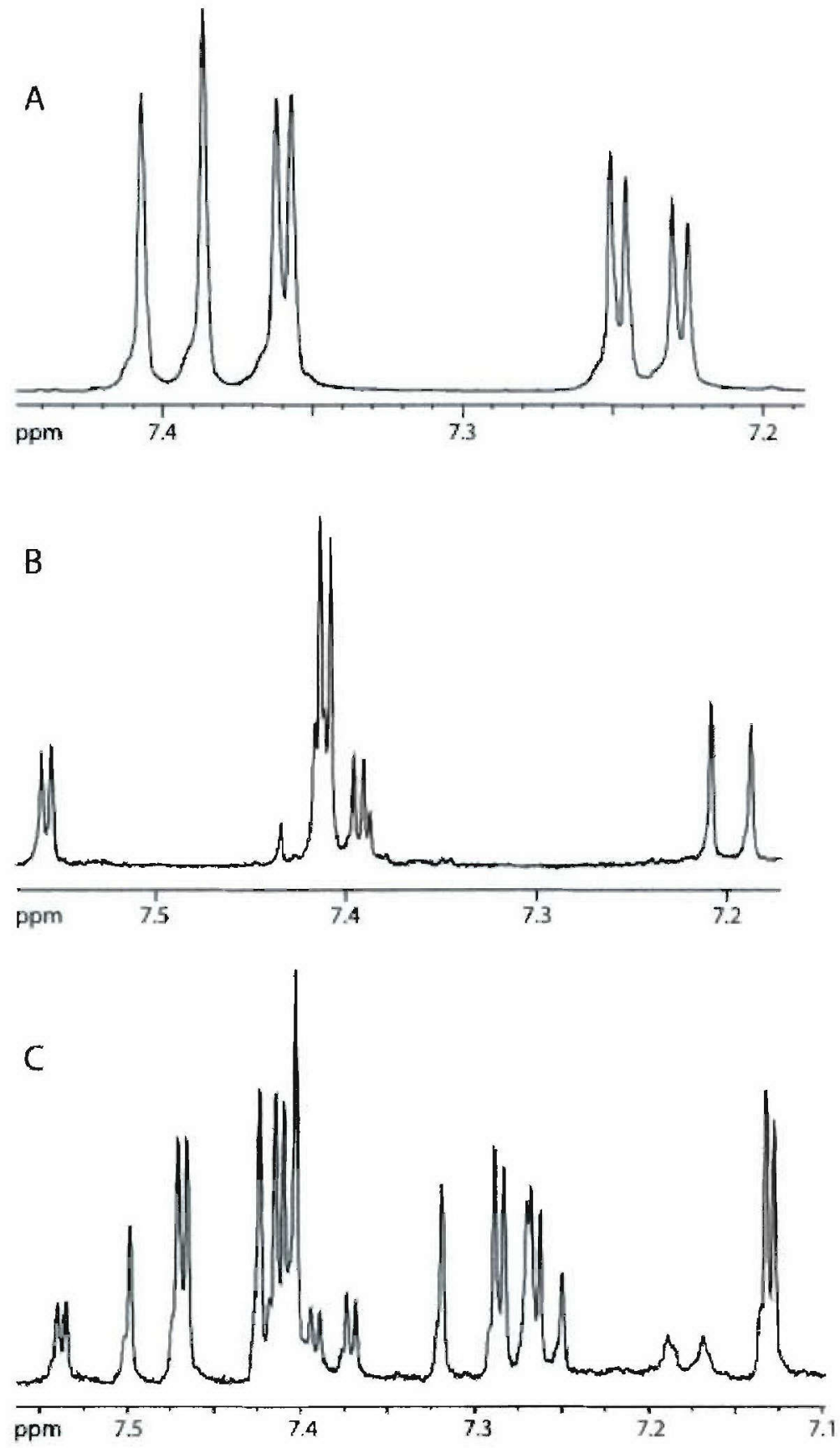

Figure 13. Proton NMR of major CDOM components in I. galbana. Major CDOM components were identified as chlorinated aromatic acids by comparison with compounds isolated from seawater. (A) 2,4-dichlorobenzoic acid, (2) tetrachloro-bipenyl carboxylic acid, and (C) a mixture of two tetrachloro-biphenyl carboxylic acids. 
(d, 2.05 Hz), 7.27 (s?), 7.26 (d, 1.9 Hz?), 7.25 (s), 7.18(? contaminant? d. 8.19 Hz), 7.13 $(\mathrm{d}, 1.98 \mathrm{~Hz})$, and therefore corresponds to a nearly $1: 1$ mixture of seawater unknowns $4 \mathrm{~A}$ and $4 \mathrm{~B}$. Fraction 5 was therefore tentatively identified as a mixture of the same TCBCAs previously isolated from seawater.

Quantitative estimates of abundance of each of the compounds produced by our cultures were obtained using a 2,4-DCBA calibration curve $\left(R^{2}=.9991\right)$. Values of 2,4 DCBA and TCBCAs in culture media from E. huxleyi and I. galbana are presented in Table 3. The blank culture revealed a peak with a retention time of 2,4-DCBA, although the identity of this compound was not confirmed by subsequent analyses. If 2,4-DCBA does occur in our blank culture the concentration is only $0.49 \mu \mathrm{g} / \mathrm{L}$, less than one percent of the concentrations found in the cultures. This indicates that culture CDOM concentrations are not greatly impacted by our processing methods, and that the chlorinated aromatic acids recovered in our analyses were biologically produced by algae or bacteria grown in culture.

Table 3. Concentrations in $\mu \mathrm{g} / \mathrm{L}$ of 2,4 -dichlorobenzoic aid and TCBCAs in culture media from E. huxleyi and I. Galbana.

$\begin{array}{lccc}\text { Culture } & 2,4-\mathrm{DCBA} & \text { TCBA-1(F4) } & \text { TCBA-2 (F5) } \\ \text { E. huxleyi } & 70 & 1.8 & 3.5 \\ \text { I. galbana } & 505 & 5.7 & 6.3 \\ \text { Blank control } & 0.49 & \text { ND } & \text { ND }\end{array}$

Our study identifies for the first time high concentrations of chlorinated aromatic acids as part of CDOM in seawater. We identified 2,4-dichlorobenzoic acid and a series of tetrachloro-biphenyl aromatic acids that are structurally related to PCBs, but synthesized by marine phytoplankton. The biological production of 2,4-DCBA and TCBCAs was confirmed by their production in laboratory cultures of marine algae. 


\section{References}

(1) DeMora, S.; Demers, S.; Vernet, M., Eds. The effect of UV Radiation in Marine Environment; Cambridge University Press: Cambridge, 2000.

(2) Carder, K.L.; Steward, R.G.; Harvey, G.R.; Ortner, P.B. Limnol. Oceanogr. 1989, $34,68-81$.

(3) Wells, M.L. In Biogeochemistry of Marine Dissolved Organic Matter; Hansell, D.A.; Carlson, C.A., Eds.; Academic Press: San Diego, 2002; pp367-404.

(4) Blough, N.V.; Del Vecchio, R. In Biogeochemistry of Marine Dissolved Organic Matter; Hansell, D.A.; Carlson, C.A., Eds.; Academic Press, San Diego, 2002; pp 509-546.

(5) Kirk, J.T.O. In Light and Photosynthesis in Aquatic Ecosystems; Cambridge Univ. Press: New York, 1994; 508 pp.

(6) Mopper, K.; Kieber, D.J. In Biogeochemistry of Marine Dissolved Organic Matter; Hansell, D.A.; Carlson, C.A., Eds.; Academic Press: San Diego, 2002; pp 455-508.

(7) Moran, M.A.; Sheldon, W.M. Jr.; Zepp, R.G. Limnol. Oceangr. 2000, 45, 12541264.

(8) Voelker, B.M.; Morel, F. M.M.; Sulzberger, B. Environ. Sci. Technol. 1997, 31, 1004-1011.

(9) Aiken, G.R.; McKnight, D.M.; Wershaw, R.L.; MacCarthy, P., Eds. Humic Substances in soil, sediment, and water; Wiley-Interscience: New York, 1985.

(10) Raymond, P.A.; Bauer, J.E. Org. Geochem. 2001, 32, 469-485.

(11) Blough, N.V.; Zafiriou, O.C.; Bonilla, J. J. Geophys. Res. 1993, 98, 2245-2257.

(12) Nelson, N.B.; Siegel, D.A. In Biogeochemistry of Marine Dissolved Organic Matter; Hansell, D.A.; Carlson, C.A., Eds.; Academic Press: San Diego, 2002; pp 547-578.

(13) Nelson, N.B.; Siegel, D.A.; Michaels, A.F. Deep-Sea Res. 1998, 45, 931-957.

(14) Coble, P.G.; Del Castillo, C.E.; Avril, B. Deep-Sea Res. 1998, 45, 2195-2223.

(15) Twardowsky, M.S.; Donaghay, P.L. J. Geophys. Res. 2001, 106, 2545-2560.

(16) Coble, P.G. Marine Chemistry 1996, 51, 325-346. 
(17) Del Castillo, C.E.; Coble, P.G.; Morell, J.M.; Lopez, J.M.; Corredor, J.E. Marine Chemistry 1999, 66, 35-51.

(18) Morelli, E.; Puntoni, F.; Seritti, A. Environ. Tech. 1993, 14, 941-948.

(19) Lombardi, A.T.; Jardim, W.F. Water Research. 1999, 33, 512-520.

(20) Parlanti, E.; Morin, B.; Vacher, L. Org. Geochem. 2002, 33, 221-236.

(21) Armador, J.A.; Milne,P.J.; Moore,C.A,; Zika, R.G. Mar. Chem. 1990, 29,1-17.

(22) Cohen, S.Z.; Nickerson, S.; Maxey, R.; Dupuy, A.; Senita, J.A. Ground Water Mon. Rev. 1990, 10, 160-173.

(23) Schwarzbauer, J.; Ricking, M.; Franke, S.; Francke, W. Environ. Sci. Tech. 2001, $35,4015-4025$.

(24) Li, Z.; Chen, X.; Zhang, Y.; Liang, X.; Wang, J.; Liang, Y. Jidi Yanjiu 1998, 10, 83-93.

(25) Brubaker, W.W.; Hites, R.A. Eniviron. Sci. Tech. 1998, 32, 3913-3918.

(26) Billingsley, K.A.; Backus, S.M.; Ward, O.P. Can. J. Microbiol. 1999, 45, 178184.

(27) Niedan, V.; Scholer, H.F. Chemosphere 1997, 35, 1233-1241.

(28) Erickson, M.D. Analytical Chemistry of PCBs, $2^{\text {nd }}$ Ed.; Chemical Rubber Company: Boca Raton, FL, 1997; 688 pp.

(29) Kitabayashi, K. National Institute Res. and Environ. 1997, Annual Report.

(30) Gribble, G.W. Pure Appl. Chem. 1996, 68, 1699-1712.

(31) Li, M.K.W.; Scheuer, P.J. Tetra. Lett. 1984, 25, 587.

(32) Tittlemier, S.; Simon, M.; Jarman, W.; Elliott, J.E.; Norstrom. R.J. Environ. Sci. Technol. 1999, 33, 26-33.

(33) Tittlemier, S.; Borrell, A.; Duffe, J.; Duignan, P.J.; Hall, A.; Hoekstra, P.; Kovacs, K.M.; Krahn, M. M.; Lebeuf, M.; Lydersen, C.; McFee, W.; Muir, D.; O’Hara, T.; Olsson, M.; Pranschke, J.; Ross, P.; Siebert, U.; Stern, G.; Tanabe, S.; Norstrom, R. Arch. Environ. Contam. Toxicol. 2002, 43, 244-255. 
(34) Neale, P.J.; Kieber, D.J. In Causes and Environmental Implications of increased $U V-B$ Radiation; Hester, R.E.; Harrison, R.M., Eds.; (The Royal Society: Cambridge, 2000; pp 61-83.

(35) Whitehead, K.; Vernetm M. Limnol, Oceanogr. 2000, 45, 1788-1796.

(36) Vernet, M.; Whitehead, K. Mar. Biol. 1996, 127, 35-44. 